\title{
CHILDREN'S SOCIAL AND EMOTIONAL DEVELOPMENT IN ISLAMIC PSYCHOLOGY PERSPECTIVE
}

\author{
Septi Gumiandari ${ }^{1}$, Selamet ${ }^{2}$, Ilman Nafia ${ }^{3}$ \\ ${ }^{1}$ Department of English Language Teaching, IAIN Syekh Nurjati Cirebon \\ Perjuangan By Pass Sunyaragi Street, Cirebon, Jawa Barat, Indonesia. 45132 \\ Email: septigumiandari@gmail.com \\ ${ }^{2}$ Postgraduate Student of Islamic Education, IAIN Syekh Nurjati Cirebon \\ Perjuangan By Pass Sunyaragi Street, Cirebon, Jawa Barat, Indonesia. 45132 \\ Email: Selametabdulsalam9@gmail.com \\ ${ }^{3}$ Department of English Language Teaching, IAIN Syekh Nurjati Cirebon \\ Perjuangan By Pass Sunyaragi Street, Cirebon, Jawa Barat, Indonesia. 45132 \\ Email: ilman.crb72@gmail.com
}

\begin{abstract}
Anti-social behaviors in children is now common. Aggressive behavior, bullying, egocentrism, fighting, prejudice and so on indicate the failure of parenting and teacher education to social and emotional development in children. This study aims to analyze the development of children's social emotions from an Islamic perspective. Through the literature study approach, there are 3 stages of social emotional development in Islam: (1) the first stage starts from birth to 7 years of age. At this stage, ethics education must be taught to children through continuous stimulus, response and imitation because the child's cognitive development is not yet perfect; (2) the second stage starts from 7 to 15 years of age. This stage is called the tamyiz stage in Islam. Children can tell the difference between good and bad. At this stage parental supervision should be increased; and (3) the third stage from 15 years of age and over. Children must already have knowledge, understanding and habits of commendable behavior, because this praiseworthy behavior is always repeated and accustomed to in the first and second stages. In this case, the family plays an important role in shaping the personality of children who are mature in dealing with problems that arise along with social and emotional development. In Islam, the problems faced by children will definitely be in accordance with their respective capacities and can still be overcome. Through problems, their faith and devotion were tested by Allah SWT. Patience and fortitude are one's potential. With intelligence given by God, children can easily know and understand the nature of every challenge and difficulty. Therefore, children must always be educated so they always have positive prejudice (busnudzan) rather than negative prejudice (su'udzan), both for themselves, others and Allah.
\end{abstract}

Keywords: children, Islamic perspective, social-emotional development

Abstrak: Perilaku antisosial pada anak kini marak terjadi. Perilaku agresif, bullying, egosentrisme, perkelahian, prasangka menunjukkan kegagalan pola asuh dan pendidikan guru terhadap perkembangan sosial dan emosional pada anak. Penelitian ini bertujuan untuk menganalisis perkembangan emosi sosial anak dari perspektif Islam. Melalui pendekatan studi pustaka, terdapat 3 tahapan perkembangan sosial emosional dalam Islam: (1) Tahap pertama dimulai dari lahir sampai usia 7 tahun. Pada tahap ini, pendidikan etika harus diajarkan kepada anak melalui pemberian stimulus, respon dan imitasi secara terus menerus karena perkembangan kognitif anak belum sempurna; (2) Tahap kedua dimulai dari usia 7 sampai 15 tahun. Tahapan ini disebut dengan tahapan tamyiz dalam Islam. Anak-anak bisa membedakan antara yang baik dan buruk. Pada tahap ini pengawasan orang tua harus ditingkatkan; dan (3) Tahap ketiga dari usia 15 tahun ke atas. Anak harus sudah memiliki pengetahuan, pemahaman dan kebiasaan berperilaku terpuji, karena perilaku terpuji ini selalu diulang dan dibiasakan pada tahap pertama dan kedua. Dalam hal ini, keluarga memegang peranan penting dalam membentuk kepribadian anak yang matang dalam menghadapi masalah yang muncul seiring dengan perkembangan sosial dan emosional. Dalam Islam, permasalahan yang dihadapi anak pasti akan sesuai dengan kapasitasnya masing-masing dan masih dapat diatasi. Melalui masalah, mereka diuji keimanan dan pengabdiannya oleh Allah SWT. Kesabaran dan ketabahan adalah potensi seseorang. Dengan kecerdasan yang diberikan oleh Tuhan, anak dapat dengan mudah mengetahui dan memahami hakikat dari setiap tantangan dan kesulitan. Oleh karena itu, anak harus selalu diedukasi agar selalu memiliki prasangka positif (busnudzan) daripada prasangka negatif (su'udzan), baik untuk diri sendiri, orang lain dan Allah.

Kata Kunci: anak, perspektif Islam, perkembangan sosial-emosional 


\section{Introduction}

Every Muslim wants to have pious children who are useful for the family, society and nation. In Islam, the Qur'an does not only contain instructions about the relationship between humans and their Gods, but also regulates the relationship between humans and others (hablum min Allâh wa hablum min al$n \hat{a s})$, and even the relationship between humans and their natural surroundings. Meanwhile, children are a mandate given by Allah SWT who must be educated in order to become pious human beings (Sholeh, 2018).

Education is one of the assets and foundations of life towards a better civilization, especially in this modern life, with increasingly sophisticated technology. How is it possible that Islam and the Indonesian nation will progress if the younger generations of successors do not have morals and good social emotional skills (Hayati \& Mamat, 2014). Therefore, it needs special attention from parents and teachers in educating children so that they continue to develop in social, technological and religious terms (Mulyani, 2014).

In the Qur'an, there are many teachings that contain the principles of how a child can properly socialize with both family and friends. Allah says in Q.S. al-Baqarah verse 195:

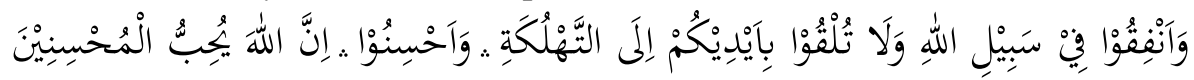

Meaning:

"And infuse (your treasure) in the way of Allah, and do not drop (yourself) into destruction with your own hands, and do good. Indeed, Allah loves those who do good."

Islam strongly recommends that its adherents have a caring nature for others or in other terms it is said to be social piety. To lead to social piety it is necessary to have education from an early age. Because whether a nation is advanced or not depends on its education pattern and the environment. However, the reality is that there are a lot of social disparities in everyday life. One example of a social case is bullying. This social case is a risk factor for children until they are adolescents (Ahyani \& Astuti, 2018). Imam Al-Ghazali argues: "Children are a mandate and responsibility of their parents, their pure pure soul is an expensive jewel that is modest and free from carvings and images. Children may accept every carving and tend to what is inclined to them" (Rohaty Mohd. Majzub in Hayati \& Mamat, 2014).

Some of the forms of social behavior that develop in early childhood are based on the foundations laid in infancy. Children develop various forms of behavior in social situations. The form of children's behavior in social situations, namely: social behavior which includes cooperation, competition, generosity, desire for social acceptance, sympathy, empathy, dependence, friendly, not egocentric, imitating, and attachment. Meanwhile, non-social behavior includes insubordination, aggression, quarrels, taunts and bullying, pretentious power, egocentricity, prejudice, and gender antagonism. Parents and teachers should carry out various appropriate stimulations so that children's socialization with the environment can develop optimally (Hurlock in Widiastuti, 2015).

In the context of education, the involvement of parents is very important, not only in the scope of funding. Parents' involvement includes all actions, starting from speaking procedures, behavior and support towards making it easier to guide quality learning for children's education. Before writing this article the authors conducted a study of several articles on children's social development. Among them is research conducted by Hayati \& Mamat (2014) entitled "Pengasuban dan Peran Orang Tua (Parenting) serta Pengarubnya terbadap Perkembangan Sosial Emosional Anak di PAUD Banda Aceh, Indonesia." The purpose of this study is to examine the relationship between parenting and social emotional development in early childhood. The results also showed a significant relationship between parenting and children's social emotional development. In this case, it can be said that the greater the role of parents, the better the children's social emotional development.

Furthermore, research conducted by Hayati (2016), "Profil Keluarga Bercerai dan Pengaruhnya terbadap Perkembangan Sosial Emosional Anak." The research objective was to describe the life of a divorced couple and the impact on children's development, especially social emotional. The results showed that all respondents experienced various disorders after the divorce, both from a psychological perspective such as withdrawal from the environment, socio-economic disorders such as difficulty in providing for a living and difficulties in child care. In addition, divorce also has a negative impact on children's social emotional 
development. Most children experience difficulties in developing self-concept, difficulty in controlling emotions, unable to build good relationships within the environment and with peers.

Other research was conducted by Yulisetyaningrum (2019), "Perkembangan Sosial Emosional Anak Usia Pra Sekolah." The purpose of this study was to determine the relationship between gender, number of siblings, parental education, parental income, family type and family parenting with the social emotional development of pre-school age children in Kramat Village, Dempet District, Demak Regency. The results and conclusions in the study indicate that there is a significant relationship between gender, number of siblings, parental education, parental income, family type and family parenting with the social emotional development of pre-school children with a $\mathrm{p}$ value of $<0.05$.

Based on the above article, there is a difference with the topic of this research, where the first article emphasizes parenting with children's social emotional development, the second article emphasizes the influence of divorced families on children's social emotional development, and the third article emphasizes parental education, income. Parents, family type, family parenting style, the influence of gender and the number of siblings on the social emotional development of pre-school age children.

Meanwhile this article discusses the social emotional development of children in an Islamic perspective. The benefits of this research are that we can analyze how children's social emotional development in an Islamic perspective, how the role of parents in educating and guiding children so that they can interact well, can be accepted by the environment in everyday life and there are no victims of bullying, or become the perpetrator, because it is clearly prohibited by Islam.

\section{Children's Social Emotional Development in Islam}

Social development is closely related to emotional development, although each of them has its characteristics. Social emotional development is a development that involves relationships and interactions with others through the feelings that a person expresses towards others and the ability to develop social and controlling behavior in terms of emotions (Wardany \& Jaya, 2017; Tusyana \& Trengginas, 2019). Davison argues that all emotions are social. The cause of emotions from our world of relationships cannot separate them, because social interactions drive emotions. The stronger the emotional connection to another person, the stronger the reciprocal power (Goleman in Radliya et al., 2017). This is also expressed by al-Ghazali "Treat others with treatment that you will surely like if the treatment is provided to you, because indeed a person's faith will not be perfect before he loves for his brother anything he loves for himself"

The information above shows that a person's faith will not be perfect until he treats his brother as he treats himself. Something he likes for himself, he will also feel happy if something is owned by his brother. Conversely, if he does not feel happy about something, then he is also not happy about something happening to his brother (Al-Ghazali, 1964; Al-Ghazali, 2006).

In this case. al-Ghazali mentioned the stages of children's social emotional development based on the concept of tamyiz (the stage where the child already has the ability to distinguish good and right) and baligh (adult).

1. First Stage: Birth to 7 Years

According to al-Ghazali, the first stage starts from birth to 7 years old. At this stage, it is very good for teaching ethics to children. At this age, the education of children can be done through providing stimulus, imitation and response because the child's cognitive development has not been perfect. For example, the stimulus given by parents is the habituation of praiseworthy behaviors, how to eat and share food with other people. Stimulus is given by parents in the form of proper and correct eating procedures, eating using the right hand, reciting doa before eating, and giving something using the right hand. When we want to give food, give proper food because however when we give something that is not good, how do we feel when in the position of the person we feed the food. When the stimulus is given, the child will imitate and display a response to the same way of eating and always share with the environment as demonstrated by both parents. Stimulus must be done repeatedly so that it will be recorded in the minds of children so that they get used to doing something right.

2. Second Stage: 7-15 Years old 
At the age of 7 and over, the child has reached the tamyiz stage, that is, the stage of the child already has the ability to distinguish between good and bad things. In this case, parental supervision must be increased. At the age of 7-15 years, children's cognitive development is better even though their development is not yet perfect. In this phase, the children are able to think in concrete terms. Children can understand when parents provide explanations why children are encouraged to behave well and are prohibited from behaving badly. However, in the second stage of development, there is still a process of imitation. Therefore, education with repetition and habituation is carried out continuously.

In this phase the child must be taught everything that is ordered and prohibited by Allah SWT. They should practice what has been learned such as prayer, Ramadan fasting, and socialize well like help in kindness and others. Besides that, they also need to be instilled in fear with despicable actions such as betraying, lying, doing heinous acts, stealing, avoiding unclean food and other despicable actions. When growing up children from an early age are accustomed to adab and other praiseworthy deeds, age of adulthood, children are used to good things and know the meaning behind all the knowledge and habits taught by their parents.

According to al-Ghazali, if the child's growth is healthy, then such an explanation when he reaches adulthood (adulthood) will definitely affect, penetrate and stick firmly in his heart. Likewise, if the child's growth is not healthy, the child will get used to spending his time saying dirty words, behaving badly, being greedy in food, and arrogant and unable to accept the above explanation. It is clear that from an early age, parenting, education, nurturing, supervision, habituation and the social environment must really be considered by parents, because a child is created with the ability to accept good and bad. His parents made him tend toward one of the two.

In the second stage, children already have the ability to think and their reasoning abilities are more developed. Al-Ghazali called it the tamyiz, stage. In Piaget's concept, children are aware that rules and laws are created and in judging an action. One must pay attention to the intentions of the perpetrators and also the consequences (Santrock in Anggraini, 2020). In addition, the second stage of development is also very close to the stage of moral development, namely conventional morality. According to Kohlberg, at this level, individual internalization is medium (Santrock in Anggraini, 2020). Conventional morality is also a stage related to assessing the rules that exist in society. This means that children are aware of the obligation to implement existing norms and maintain the importance of the existence of norms.

3. Third Stage: 15 Years and above

Age 15 years and over is the age of adulthood in a child. This means that at the age of 15 , the child should already have knowledge, understanding and commendable behavior habits. Because this praiseworthy behavior is always repeated and accustomed to in the first and second stages. The praiseworthy behavior is inherent so that the child has a spontaneous response, has an understanding and thought about the consequences of every action, that what is done is a self-concept as a servant of God so that each behavior is adjusted to Islamic law and has become a character, so that the child will always have a commendable character.

The third stage is the result of the formation of the first and second stages. In this third stage, the role of reasoning begins to disguise. It does not mean that it is not important or non-functional, but rather that when there is a stimulus, the response is in the form of a permanent and spontaneous response. This is because of habituation from an early age, so that the child has praiseworthy behavior that has become a character in him.

In Western literature, the concept that is close to character in morals is known as the four component model of morality. The four aspects are moral sensitivity, moral judgment, moral motivation and moral character. The moral character seems close to the concept of akblak in Islamic psychology (Anggraini, 2020).

\section{The Role of Family in Children's Social Emotional Development in Islam}

Emotional social development is a process of learning to adapt, to understand circumstances and feelings when interacting with people in their environment, whether parents, siblings, peers or other people in their daily life (Zulkifli in Yulisetyaningrum, 2019). In this case, the growth and development 
of children is influenced by many factors, including mother's education, mother's work, father's education, developmental stimulation and environmental factors of the child (Wulandari et al., 2017).

Al-Qur'an instructs mankind to always look after and educate children properly, as Allah says:

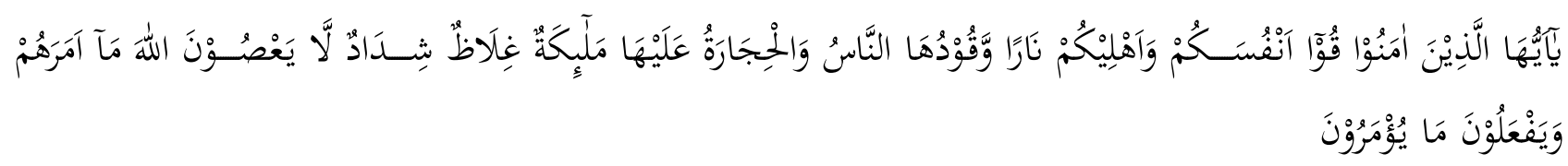

Meaning:

"O you who believe! Protect yourself and your family from the fires of hell, whose fuel is people and stone; guardian angels are harsh, and harsh, who do not disobey God against what He commanded them and always do what is commanded."

Imam Al-Ghazali affirmed that "Children are a mandate and responsibility of their parents, their pure pure soul is an expensive jewel that is modest and free from carvings and images and he may accept every carving and tend to what is inclined to him" (Hayati \& Mamat, 2014). Based on the explanation, family plays an important role in providing educators to children. What is meant by family is the smallest unitary element consisting of a father, mother and several children. Each of these elements has an important role in fostering and enforcing the family, so that if one of these elements is lost, the family will be shaken or less balanced.

The relationship between mother, father, and child serves as a milestone in all relationships that an individual will establish throughout his life (Hall in Jasmi et al., 2012). The relationship between parents and teachers also plays an important role in the progress of children in the educational process, both in intellectual and psychological aspects. Parents are responsible for educating children in the overall process of child development, both intellectual development by providing scientific facilities and support, as well as psychological development by being a protector for a child (Kadir et al., 2015; Tahir \& Larmar, 2020).

One of the hadiths of the Prophet explains (Jasmi et al., 2012) that Ayyub bin Musa from his father from his grandfather that Rasulullah s.a.w. said: "There is nothing more important that can be given by a father than good manners (morals)." (Al-Tirmidhi).

The hadith above shows how important family is in educating a child. Because in the current era of revolution 4.0, moral education must continue to be improved. Because the family function as expressed by Friedmen (Hayati, 2016) is as follows:

1. Affective function. Family is a place to teach everything that can prepare family members to relate to other people.

2. Socialization function, namely a place to develop and train children so that their social life is good. Before leaving home, children are able to build social relationships with other people outside the home.

3. Reproductive function, namely a place to maintain generations and maintain family continuity.

4. Economic function, namely a place to meet family needs economically and develop individual abilities to increase income in order to meet family needs.

5. The health maintenance function, which is appropriate for maintaining the health of family members in order to maintain high productivity.

\section{Problems in Children's Social Emotional Development from Islamic Review}

Social problems faced by children include the child's desire to win alone, pretend to be powerful, do not want to wait their turn when playing together, always want to be noticed, pick and choose friends, aggressive by attacking other children, seizing toys or other people's belongings, breaking things, and being unable to adapt to new environments (Saleh et al., 2017).

Various opinions say, when a child experiences a problem that exceeds the limits in general, the main causative factor is his family. The family is a group of two or more individuals who are linked by birth, marriage, or adoption and live together and share other social functions with one another (Bureau in Setyaningsih, 2016). 
Likewise, the problem of bullying that comes from a social ecological perspective. How this bullying behavior is formed not only by individual characteristics but also by the contextual system of schools, peer groups, teacher-student relationships, parent-child relationships, parent school relations, environment, and culture or society (Ahyani \& Astuti, 2018; Ganjvar, 2019).

Bullying behavior can be in the form of threats that a person makes to other people in general who are weaker or lower than the perpetrator. This kind of behavior will unconsciously cause psychological disturbances in the victim in the form of stress and can also affect physical or psychological disorders, or both. Some examples of the impact of bullying are for example: difficulty ini eating, physical pain, fear, low self-esteem, depression, anxiety, and others. In addition to the feelings that were received, a Bully victim also felt anger and resentment with what happened to them. There are also feelings of anger, shame and disappointment with themselves for "letting" the incident happen to them. In this case, Islam provides an overview of the problems of children's social emotional development as said by Allah SWT in Q.S Al Hujurat: 11

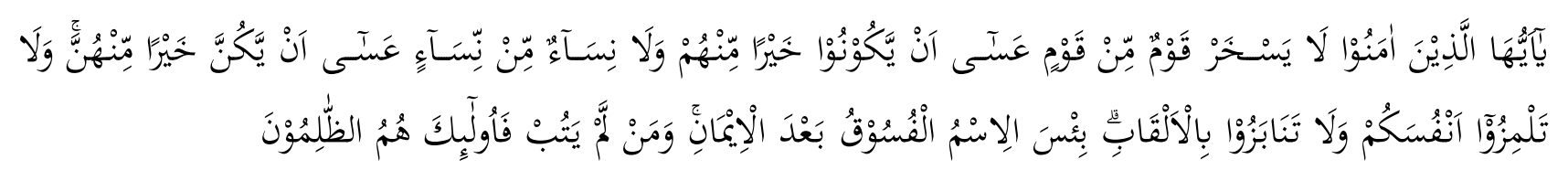

Meaning:

"O you who believe! a people should not make fun of other people (because) they (who are being mocked) are better than them (who make fun of) and women (make fun of) other women (because) women (who is being teased about) can be better than the woman (who makes fun of him). Do not criticize each other and do not call each other with bad titles. The worst call is wicked (fasil) after believing (iman). And whoever does not repent (taubat), they are the wrongdoers (zalim)."

The above verse refers to the "ridicule" made by the Bani Tamim group against the poor companions of the Prophet such as Bilal, Shuhaib, Salman al-Faris, Salim Maula Abi Huzaifah, etc. Another narration states that this verse deals with the "mockery" of some women to Shafiyah bint Huyay bin Akhtab, one of the Prophet's wives from Jewish descent. The Prophet then said to Shafiyah: "why don't you tell them that my father is Prophet Harun, my uncle is Prophet Musa and my husband is Prophet Muhammad?!" (Hosen, 2017).

From the explanation above, it can be understood that behaviors to insult or harass one another because of someone's shortcomings, their descendants of different religions or because their family has disgrace are despicable behaviors. The message of the Qur'an is extraordinarily powerful: "it may be that what you make fun of is better than what is made fun of by Allah." Harassing or looking down on other people is strictly prohibited in the teachings of Islam because it creates feelings of shame for the victim. The victim will feel his own honor being dropped, and there is also a feeling that the person who is bullying is better than others so that he has the right to harass them, or there may be jealousy that other people are better than him and to cover up his dislike of their strengths. Humans are prohibited from bullying others, destroying the honor of others, having arrogant feelings, feeling better than others or being jealous/envy another advantage. All of those bad behaviors are not justified in Islamic teachings.

Islam teaches how to make friends properly. In this case Al-Ghazali argues: First, humans are like food. We may not be able to escape from food as long as we are alive. This means that as social beings, humans cannot live alone without the help of others. So, let's have good morals so that we can get good food intake through our mua'syaroh with noble morals. Second, humans are like medicine. Sometimes we need it when we are sick and sometimes we have to stay away from drugs so we don't overdose. In this context, make sure that we don't make the wrong choice of friends as we don't misdiagnose a disease and end up taking the wrong medication. If we make the wrong choice of friends, it is the same as taking the wrong medicine. It is not a healthy body that we feel, but it can be poisoned. Likewise, when we choose the wrong friends, we will not get benefit, but instead harm and danger that we will feel. Third, humans are like diseases. Stay away from this third type. We should not look for this human model as a friend, because in addition to damaging ourselves, we will also pass on the badness to others. As a disease that will transmit to others, we must stay away from and prevent friends with this third type (Al-Ghazali, 1964, 2006). 
During middle and late childhood, a teenager should ideally be able to spend time interacting with peers regarding the social interests that adolescents should develop at their age. Teenagers conversation in talking about certain things that bother them is very important, because they will get new views of the problems they are facing and they will face (Hurlock in Ardi et al., 2012).

The inability of individuals to control themselves can cause various social problems with other people. If this social-emotional problem is ignored, it will develop into a wider and more complex problem because the child will develop into a worse direction, the formation of a bad personality and result in the emergence of unexpected negative behaviors (Astuti, 2013). According to Skinner's theory of Behaviorism (Ngura, 2018), the ability to speak and understand language is obtained through environmental stimuli. Interactions with children help them form views about what culture expects them (Mukhlis and Mbelo, 2019).

Al-Quran has many teachings that contain the principles of how children can socialize well. One of them is in Q.S Ali 'Imran verse 159:

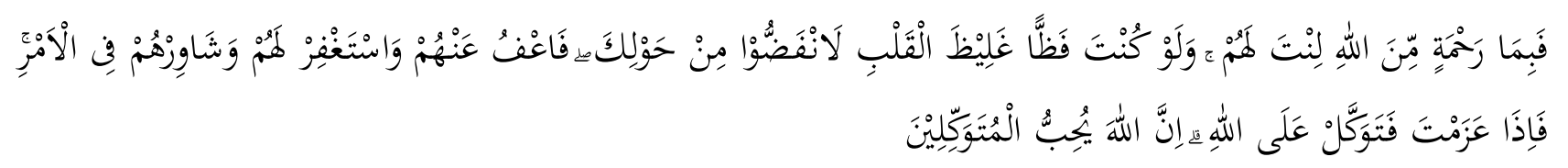

Meaning:

"Then thanks to the grace of Allah you (Mubammad) were gentle towards them. If you are hard-hearted and harsh-hearted, they will certainly distance themselves from around you. Therefore forgive them and ask forgiveness for them, and consult with them in this matter. Then, when you have made up your mind, then put your trust in Allah. Indeed, Allah loves those who put their trusts in."

Al-Qur'an teaches us how to behave in socialization, including how we behave gently, always give forgiveness and when problems occur, are willing to carry out deliberation. Social and emotional intelligence becomes the foundation for development in interacting with the wider environment. In interacting with other people, individuals are not only required to be able to interact well with others, but also how they are able to control themselves properly. When individuals are unable to control their social emotional intelligence, they can cause various social and emotional problems with other people. Conversely, children who have good social and emotional intelligence will be able to adapt well to their environment, family, school and friends (Imron, 2018).

According to developmental psychologists, good relationships between peers have an important role in normal development, which in this case is the socio-emotional development of children (Desmita in Latifah et al., 2010). The factors that support a person's success are cognitive intelligence, while the other is maturity in social emotions. This emotional social maturity is needed by individuals to be able to cope with pressures and not easily get frustrated by the circumstances around them (Megawangi in Hastuti et al., 2011).

One precaution that can be taken is to create a child-friendly school environment. Based on the research results of Ahyani \& Astuti (2018), it shows that when a teacher has empathy, emotional regulation and high self-efficacy, the tendency to bully students is low (Ahyani \& Astuti, 2018).

\section{Resilience of Children's Emotional Social Development in Islamic Review}

Resilience is a personal quality that allows a person to develop in the midst of the difficulties he/she is facing. Resilience can also be seen as a measure of a person's ability to cope with stress, where this can be a target for healing anxiety, depression, and stress reactions (Connor \& Davidson in Andriani \& Listiyandini, 2017). So, it can be concluded that resilience is a personal quality in the form of a person's ability to cope with stress, which allows that person to thrive in the midst of the difficulties he/she faces.

Theologically, the Qur'an is the most complete book that regulates human life, even all entities in this life, including education and various other social dimensions (Fauzi in Wahidah, 2020), as well as 
about rising from adversity (resilience), as explained in QS al-Baqarah verse 214 and in the context explained again in QS al-Baqarah verses 155-156:

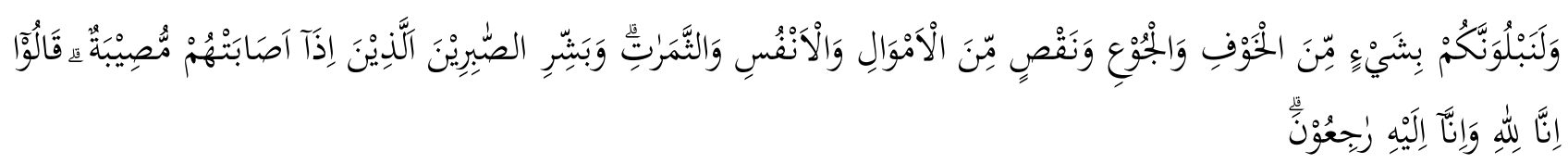

Meaning:

"And We will certainly test you with a little fear, bunger, lack of wealth, souls, and fruit. And give good news to those who are patient, (that is) people who, when disaster strikes, they say "Inna lillabi wa inna ilaibi raji'un" (we actually belong to Allah and to Him we return)."

The word of God above can be interpreted that, there is not a single person in this world who is not given a problem by God. By surrendering everything that happens to God and everything in this world that belongs to Him, a person's soul will feel calm and avoid disappointment and despair. And only people who are able to survive in solving problems and are able to rise again, they will get pleasure from Allah in return for their success in facing problems. From this it can be understood that resilience in Islam is an obligation. Having resilience means that a servant has tested his faith and toughness as a Muslim. In a hadith, it is said that Allah SW'T loves his strong servants than his weak servants, as explained in Q.S Al Baqarah, verse: 286 and Asy-Syarh verses 6-8:

Meaning:

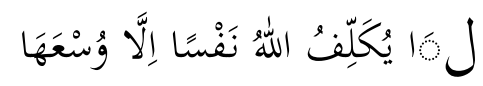

"Allab does not burden a person except according to bis ability."

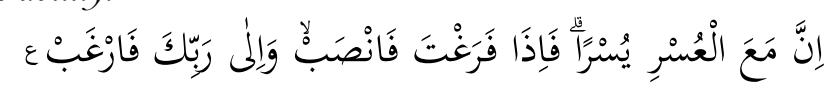

Meaning:

"In fact, along with difficulties, there is ease/convenience. So when you have finished (from one business), keep working hard (for other matters), and only in God you bope."

The two verses mentioned above explain that humans are motivated to have resilience after getting life's problems, because in fact, the problems faced are according to human capacity and can still be overcome. Faith is not said to be tough if it has not been tested. Through problems, trials and other temptations, humans are tested for their faith and devotion by Allah SWT. Therefore, people who are patient and steadfast is one of the characteristics that they have resilience. Patience and fortitude are the potentials of every human being. There are different levels of patience and steadfastness in a person, and it is necessary to train them so that patience can grow in a person. That is the reason Islam always invites its people to be patient servants, and Allah loves His patient servants. Not only struggling with one's own abilities in the Islamic concept, there are also prayers and hopes that motivate Muslims to be successful and achieve their goals.

Based on the Q.S. Al-Insyirah, there are two verses that are repeated, "along with difficulties there is ease/convenience." This verse gives the spirit that every human being will seriously contemplate that difficulties, misery, misfortune, and pain are the doors to enter into the secret and essence of ease, happiness, and peace. With this intelligence, one can easily know and understand the nature of every challenge and difficulty. Therefore, someone will always have the spirit to always look for ways and gaps in order to penetrate the essence of challenges and suffering through struggle and sacrifice (Adz-Dzakiey, 2005; Wahidah, 2020).

Social Emotional development is the process of forming children's personality in society: their personality in the family, culture, nation, and so on (Muhibin in Aprianti, 2018). Various methods are used to develop a child's social, emotional and spiritual abilities in life, including:

a. Husnudzan

Husnudzan is prejudice towards someone before the truth is known with certainty. On the contrary, su'udzan is prejudice against someone before the exact truth is known. This is in line with the word of Allah Q.S Al-Hajj verse 15. 
Husnudran's attitude is not only shown to humans, but also to Allah SWT and themselves. Husnudzan to Allah SWT is obligatory and can be shown by always being kind to Him. Because Allah SWT Who has created the universe and everything in it with careful planning, created humans with all their strengths and weaknesses, giving treasure fairly and wisely.

Muhammad Nashir in Faizah (2018), there is no reason for us to su'udzan to Allah SWT. As the Prophet SAW said. "I am according to the prejudice of My servant towards Me. And if he's prejudiced well, then it's good for him. If he has a bad prejudice, then that is bad for him (Ahmad Ibn Hibban and al-Baihaqi). Husnudzan to Allah SWT can also be shown by receiving His qodho and qodar, being grateful for all His favors and gifts, feeling His love and compassion and so on.

b. Husnudzan to fellow humans.

Humans are social creatures where one another cannot be separated and need each other. However, in human relationships there are often social conflicts caused by many things, including prejudice. Because of the conflict, the relationship that had been established for so long time was cut off. Islam teaches us all to always busnudzan in facing various problems and keep away from prejudice (su'udzan). Allah says in Q.S. al-Hujurat verse 12. This verse shows us that being busnudzan to fellow humans will lead to good feedback by others, namely positive attitudes and responses from others and a strong bond of friendship will be built, life will be even more harmonious.

c. Husnudzan toward oneself

Every human being was created by Allah SWT with all its advantages and disadvantages. The advantages given by Allah SWT must be used as best as possible in matters of goodness as a form of our gratitude to Him. As for our shortcomings, we must respond positively and do not present any prejudice within ourselves.

The way to cultivate busnudzan's attitude towards ourselves is to be grateful for all the blessings given by Allah, including the potential that we have. If this attitude can be developed properly, it will foster self-confidence and always be optimistic in facing all the problems of life. Conversely, if we always have negative prejudice (su'udzan) towards ourselves and are not grateful for the blessings and gifts of Allah SWT, then an attitude of despair and always pessimism will emerge in facing all of life's problems. In the end, we can't realize the potential we have, and we can't develop it to the fullest. Thus, in turn, we will persecute ourselves, as Allah SW'T says in Q.S Huud verse 9.

Husnudzan towards oneself can be shown by not giving up easily and hopeless in facing the problems of life in this world, always optimistic and persistent in doing something, dynamic in developing one's potential and others.

\section{Conclusion}

This study reveals that there are 3 stages of social emotional development according to Islam: (1) The first stage starts from birth to 7 years old. In this stage, ethics should be taught to children through providing stimulus, imitation and response because the child's cognitive development has not been perfect; (2) The second stage start from 7 to 15 years old. This stage called by tamyiz stage in Islam. Children can distinguish between good and bad things. In this stage, parental supervision must be increased; and (3) The third stage from 15 years and above. Child should already have knowledge, understanding and commendable behavior habits, because this praiseworthy behavior is always repeated and accustomed to in the first and second stages.

Family plays an important role in providing educators to children in the process of developing their social emotional development in Islam. In Islam, the problems are always existed in humans' life. The problems faced by humans including teenagers are according to their own capacity and can still be overcome. Through problems, humans are tested for their faith and devotion by Allah SWT. Patience and fortitude are the potentials of every human being. With the intelligence given by God, one can easily know and understand the nature of every challenge and difficulty. Therefore, humans should have positive prejudice (busnudzan) rather than negative prejudice (su'udzan), even for themselves, other people and Allah. 


\section{References}

Adz-Dzakiey, H. B. 2005. Prophetic Intelligence. Yogyakarta: Islamika.

Ahyani, L. N., \& Astuti, D. 2018. Buku Ajar Psikologi Perkembangan Anak dan Remaja. Kudus: Universitas Muria Kudus.

Al-Ghazali, I. 1964. Bidayatul Hidayah. Magelang: Menara Kudus.

Al-Ghazali, I. 2006. Ayyuhal Walad. Surabaya: Al-Haramain.

Andriani, A., \& Listiyandini, R. A. 2017. Peran Kecerdasan Sosial terhadap Resiliensi pada Mahasiswa Tingkat Awal. Psympatbic: Jurnal Ilmiah Psikologi, 4(1), 67-90.

Anggraini, F. 2020. Psikologi Perkembangan Akhlak Perspektif Al-Ghazali (Kajian Kitab Ihya'Ulumuddin Bab Riyadhah An-Nafs). Jurnal Syntax Transformation, 1(7), 312-322.

Aprianti, E. 2018. Penerapan Pembelajaran BCM (Bermain, Cerita, Menyanyi) Dalam Konteks Perkembangan Sosial Emosional Anak Usia Dini Di Kober Baiturrohim Kabupaten Bandung Barat. Tunas Siliwangi, 3(2), $195-211$.

Ardi, Z., Ibrahim, Y., \& Said, A. 2012. Capaian Tugas Perkembangan Sosial Siswa dengan Kelompok Teman Sebaya dan Implikasinya terhadap Program Pelayanan Bimbingan dan Konseling. Konselor, 1(2), 1-8.

Astuti, M. 2013. Implementasi Program Fullday School Sebagai Usaha Mendorong Perkembangan Sosial Peserta Didik TK Unggulan Al-Ya’lu Kota Malang. Jurnal Kebijakan dan Pengembangan Pendidikan, 1(2), 133-140.

Faizah, H. B. 2018. Pendidikan Agama Islam. Jakarta: Yayasan Pesantren Islam Al Azhar.

Ganjvar, M. 2019. Islamic Model of Children's Spiritual Education (CSE); Its Influence on Improvement of Communicational Behaviour with Non-Coreligionists. International Journal of Children's Spirituality, 24(2), 124 139.

Hastuti, D., Fiernanti, D. Y. I., \& Guhardja, S. 2011. Kualitas Lingkungan Pengasuhan dan Perkembangan Sosial Emosi Anak Usia Balita di Daerah Rawan Pangan. Jurnal Ilmu Keluarga \& Konsumen, 4(1), 57-65.

Hayati, F. 2016. Profil Keluarga Bercerai dan Pengaruhnya terhadap Perkembangan Sosial Emosional Anak. Buah Hati Journal, 3(2), 1-10.

Hayati, F., \& Mamat, N. 2014. Pengasuhan dan Peran Orang Tua (Parenting) serta Pengaruhnya terhadap Perkembangan Sosial Emosional Anak di PAUD Banda Aceh, Indonesia. Buab Hati Journal, 1(2), 16-30.

Hosen, N. 2017. Tafsir al-Quran di Medsos. Yogyakarta: Bentang Bunyan.

Imron, R. 2018. Hubungan Penggunaan Gadget dengan Perkembangan Sosial dan Emosional Anak Prasekolah di Kabupaten Lampung Selatan. Jurnal Ilmiah Keperawatan Sai Betik, 13(2), 148-154.

Jasmi, K. A., Hong, F. C., \& Shamsuddin, S. D. 2012. Perkembangan Sosial Anak dan Hubungannya dengan Rakan Sebaya. In Prosiding Seminar Pertama Sains, Teknologi, dan Manusia. Marbawy Hall, Faculty of Islamic Civilization, Universiti Teknologi Malaysia: 22 September 2012. pp. 77-95.

Kadir, A., Fauzi, A., Yulianto, E., Baehaqi, Kurnianto, R., \& Rosmiati. 2015. Dasar-Dasar Pendidikan. Jakarta: Kencana.

Latifah, E., Hastuti, D., \& Latifah, M. 2010. Pengaruh Pemberian ASI dan Stimulasi Psikososial terhadap Perkembangan Sosial-emosi Anak Balita pada Keluarga Ibu Bekerja dan Tidak Bekerja. Jurnal Ilmu Keluarga \& Konsumen, 3(1), 35-45.

Mukhlis, A., \& Mbelo, F. H. 2019. Analisis Perkembangan Sosial Emosional Anak Usia Dini Pada Permainan Tradisional. Preschool (Jurnal Perkembangan Dan Pendidikan Anak Usia Dini), 1(1), 11-28.

Mulyani, N. 2014. Upaya Meningkatkan Perkembangan Sosial Emosional Anak Usia Dini. Jurnal Ilmiah Mahasiswa Raushan Fikr, 3(1), 133-147.Ngura, E. T. 2018. Pengembangan Media Buku Cerita Bergambar untuk Meningkatkan Kemampuan Bercerita dan Perkembangan Sosial Anak Usia Dini Di TK Maria Virgo Kabupaten Ende. Jurnal Ilmiah Pendidikan Citra Bakti, 5(1), 6-14.

Radliya, N. R., Apriliya, S., \& Zakiyyah, T. R. 2017. Pengaruh Penggunaan Gawai terhadap Perkembangan Sosial Emosional Anak Usia Dini. Jumal PAUD Agapedia, 1(1), 1-12.

Saleh, Y. T., Nugraha, M. F., \& Nurfitriani, M. 2017. Model permainan tradisional "boy-boyan" untuk meningkatkan perkembangan sosial anak SD. ELSE (Elementary School Education Journal): Jurnal Pendidikan Dan Pembelajaran Sekolah Dasar, 1(2b), 127-138.

Setyaningsih, W. 2016. Hubungan Pola Asuh Orang Tua dengan Perkembangan Sosial Anak Autisme di SLB Harmoni Surakarta. Jurnal Kesebatan, 6(2), 123-129.

Sholeh, M. 2018. Pendidikan Anak Usia Dini dalam Perspektif Pendidikan Islam. Yinyang: Jurnal Studi Islam Gender dan Anak, 13(1), 71-83.

Tahir, M., \& Larmar, S. 2020. Conceptualizing the development of personality in children: An analysis of Islamic philosophy and contemporary Western psychology. Agathos: An International Review of the Humanities and Social Sciences, 11(1), 192-215. 
Tusyana, E., \& Trengginas, R. 2019. Analisis Perkembangan Sosial-Emosional Tercapai Siswa Usia Dasar. INVENT A: Jurnal Pendidikan Guru Sekolah Dasar, 3(1), 18-26.

Wahidah, E. Y. 2020. Resiliensi Perspektif Al Quran. Jurnal Islam NUsantara, 2(1), 105-120.

Wardany, M. P., \& Jaya, M. T. S. 2017. Aktivitas Bermain Kooperatif Meningkatkan Perkembangan SosialEmosional Anak. Jurnal Pendidikan Anak, 3(2), 1-9.

Widiastuti, R. Y. 2015. Dampak Perceraian pada Perkembangan Sosial dan Emosional Anak Usia 5-6 Tahun. Jurnal PG-PAUD Trunojoyo: Jurnal Pendidikan dan Pembelajaran Anak Usia Dini, 2(2), 76-86.

Wulandari, R., Ichsan, B., \& Romadhon, Y. A. 2017. Perbedaan Perkembangan Sosial Anak Usia 3-6 Tahun Dengan Pendidikan Usia Dini dan Tanpa Pendidikan Usia Dini di Kecamatan Peterongan Jombang. Biomedika, 8(1), 47-53.

Yulisetyaningrum, Y. 2019. Perkembangan Sosial Emosional Anak Usia Pra Sekolah. Jurnal Ilmu Keperawatan dan Kebidanan, 10(1), 221-228. 